\title{
Socio-Legal Perspectives on Gender, Sexuality and Law: Editorial
}

\author{
Chris Ashford
}

Published online: 29 April 2010

(C) Springer Science+Business Media B.V. 2010

\section{Introduction}

This special edition of Liverpool Law Review offers four articles that consider contemporary issues in Gender, Sexuality and Law. They are united by the sociolegal approach that they take to a range of global social phenomena and were each originally presented as part of the Gender, Sexuality and Law stream at the 2009 Socio-Legal Studies Association (SLSA) Annual Conference in Leicester. Each piece highlights the importance of socio-legal approaches to the examination of gender and sexuality in both domestic and international legal discourses and this editorial sets forth some of the issues in developing the 'field' of gender, sexuality within a socio-legal context.

\section{Defining Socio-Legal}

Drawing a collection of work under the banner 'socio-legal' is, despite the modern commonality of the term, not without problems. ${ }^{1}$ Philip Thomas has described the difficulties in defining Socio-Legal Studies ${ }^{2}$ whilst Nelkin has noted the very term 'socio-legal' can be contentious amongst those who prefer the term 'Sociology of Law' $^{3}$ and who seek to draw a distinction between the two. ${ }^{4}$ This distinction, or boundary, Banakar and Travers argue, is 'an obstacle which hinders the

\footnotetext{
1 Cownie (2004a): 51.

2 Thomas (1997).

3 Nelkin (1981). See more generally: Cotterrell (1995).

4 See Travers (2001).

C. Ashford $(\bowtie)$

University of Sunderland, Sunderland, Tyne and Wear, UK

e-mail: chris.ashford@sunderland.ac.uk
} 
development of the social-scientific study of law'. ${ }^{5}$ They rightly note the increased sophistication which legal scholars show in their awareness of sociology and related fields. ${ }^{6}$ For example, in researching issues of gender, sexuality and law, it would not be unusual to consult with literature in sociology, psychology, history, media, politics, cultural studies, geography, anthropology, criminology and of course sexology. The strength of the Socio-Legal Studies Association Annual Conference, and similar conferences such as the Law and Society Association in the United States is that they seek to bring these scholars together under the heading socio-legal. Yet, that heading can still mean different things for different people.

An excellent and enduring definition of the term is that of Bradshaw ${ }^{7}$ who indicated that: "in both topic and locus of study, socio-legal research moves beyond legal text to investigate law-in-society. Consequently, traditional legal reasoning and the focus on codes and cases of law are not the primary concerns of socio-legal study.'

This does give rise for debate as to how much those codes and cases should feature, if indeed at all. In the continuum of scholarship, where we place ourselves and how we are labelled defines career routes, and the work and language that might be acceptable in our scholarly field. Alan $\mathrm{McKee}^{8}$ recently highlighted one example whereby the term 'titwank' could be used in humanities but not in the social sciences. McKee adds: 'there are many 'fucks' in queer theory'. Law's ability to navigate around the traditional boundaries of humanities and social sciences can give socio-legal scholars something of an advantage in exploring these issues. Definition of field therefore, appears to be important not only for what we say, but how we say it.

Thomas ${ }^{9}$ notes the division between the USA experience where the Law and Society Association is dominated numerically by non-lawyers from non-ivy league universities whilst the SLSA in the UK is 'dominated by academic lawyers from 'old' law schools'. Thirteen years later, Thomas' observation seems a little less straight forward.

Based on anecdotal experience, it remains the case that the US Law and Society Association offers a greater mix of scholars from a range of disciplines including sociology, anthropology, psychology and law, whilst the UK conference remains more focussed on legal scholars. A number of years ago, I was returning from the Law and Society Annual Meeting and found myself sitting at the departure gate next to another UK scholar. She was a sociology Professor but for her the SLSA was "too full of lawyers" and so her only socio-legal conference remained one that necessitated travelling across the Atlantic Ocean.

\footnotetext{
5 Banakar and Travers (2005).

${ }^{6}$ Despite this growing sophistication, individual interpretation of socio-legal amongst scholars does vary. See for example: Carline and Baker (2008).

7 Bradshaw (1997).

${ }^{8}$ McKee (2009).

9 Thomas (1997).
} 
This remains a challenge for the SLSA and organisations like it. Nonetheless, the tilt towards a law focus appears to remain reflected in the membership of the society and in the recent Research Assessment Exercise (RAE) panel memberships for sociology, social policy, politics and psychology. ${ }^{10}$

Literature around socio-legal studies has been peppered with fears about the future of the 'discipline' or 'field' with concerns expressed about empirical sociolegal research, ${ }^{11}$ the impact of the RAE, ${ }^{12}$ a lack of socio-legal training in Law Schools, ${ }^{13}$ and the impact of government's policy proposals and initiatives. ${ }^{14}$ Despite these concerns, there have also been positive developments. Cownie has noted that socio-legal research may be more widely spread within UK law schools than previously thought, noting that 'the socio-legal approach may actually be more influential than the doctrinal'. ${ }^{15}$ Of course, much depends upon our variant conceptions of socio-legal.

The most recent RAE did not comment explicitly on socio-legal studies in its overview, describing legal scholarship more generally as being 'in a healthy state'. There has been extensive comment upon the 1994 ESRC review of socio-legal research. ${ }^{16}$ The review came just 4 years after the founding of the SLSA in the UK and came in the wake of a decision to end core funding of the Oxford Socio-Legal Centre. It acted as a means to both explore the then situation of socio-legal studies and also as a voice of concern about the ESRC's findings which concluded in its report that: 'there is a shortage of staff within law departments to provide training in socio-legal research, and social science departments do not have legally trained academics who can assist in developing an interest in, and knowledge about, law as a focus for research activity'. ${ }^{17}$ Despite these concerns, expressed over 15 years ago, socio-legal studies has continued its inexorable rise.

By 1995, Twining noted that socio-legal conference programmes were reflecting themes of 'diversity, increased sophistication and confidence'. ${ }^{18}$ Yet, with this increased sophistication, questions about the extent to which socio-legal studies is more about 'law' or the "social' 19 remain. The bringing together of a grand coalition of disciplines noted above invariably means different languages, methodologies and theories are poured into the melting pot that can be socio-legal studies. Gender, Sexuality and Law, with its similarly diverse constituency of scholarship, can therefore be both analogous to, and a constituent part of, socio-legal study.

\footnotetext{
10 Wheeler (2009).

11 Genn et al. (2006) and Hillyard (2007).

12 Hillyard (2002).

13 Cowan et al. (2003) and Witherspoon (2002). See more generally: Burns and Hutchinson (2009). Questions about depth of understanding have long dogged socio-legal study. See for example Galligan (1995) and for a response Voiculescu (2008).

14 Collier (2003, 2004) and Bibbings (2003).

15 Cownie (2004b).

16 See for example: Hunt (1994), Partington (1997) and Thomas (1997).

17 ESRC (1994).

18 Twining (1995).

19 Fitzpatrick (1995).
} 
More recently Cotterrell has sought to 'tilt' socio-legal study towards a focus on power and reassert links between law and morality. Of power Cotterrell writes 'Most socio-legal work explores the power of the law: how it is structured and organized, its consequences and sources, and the way people and organizations seek to harness it, have differential access to it or find themselves differentially affected by it. ${ }^{20}$

The similar focus of so much gender, sexuality and law scholarship on themes of power and morality - notably the influence of Foucault-renders socio-legal studies a logical home for this scholarship. ${ }^{21}$

As has already been noted, the SLSA was established in 1990 in the UK with an aim to provide an annual forum for socio-legal scholars to disseminate their work. ${ }^{22}$ Nineteen years later, the Association restated its principles, and included a definition of socio-legal study:

'Socio-legal studies embraces disciplines and subjects concerned with law as a social institution, with the social effects of law, legal processes, institutions and services and with the influence of social, political and economic factors on the law and legal institutions.'

The SLSA statement also recognizes the diverse nature of socio-legal scholarship, adding: 'Socio-legal research is diverse, covering a range of theoretical perspectives and a wide variety of empirical research and methodologies. ${ }^{23}$

Socio-legal can therefore provide a 'safe home' for Gender, Sexuality and Law scholars beyond their ordinary disciplinary boundaries. This notion of a 'home'24 has been stated as important by academics in this field and that resonates with traditional activism that sees LGBTQ rooms and spaces provided in universities and colleges and in more visible forms such as annual Pride events. We know the notion of 'safe space' is important in the construction of commercial social spaces for LGBTQ audiences ${ }^{25}$ and so we should not be surprised that there is a need for a similar space of scholarship. The fluidity of socio-legal-and the inclusivity that stems from it is its great strength.

The SLSA, and its annual conference should perhaps therefore be seen as fertile ground for those scholars engaged in work within the broadly conceived 'field' of gender, sexuality and law, bringing together a set of players well suited to engage in what might be considered a multi-disciplinary field, albeit, as we will see, a 'field' which is itself rife with difficulties of definition.

\footnotetext{
${ }^{20}$ Cotterrell (2002), Lacey (1998): 198.

21 See more generally: Golder and Fitzpatrick (2009)

22 http://www.kent.ac.uk/nslsa/content/view/56/250/ (Accessed 9 December 2009).

23 SLSA (2009).

24 See for example: Moran (2009).

25 Moran et al. (2004).
} 


\section{Gender, Sexuality and Law}

In June 2004, the Arts and Humanities Research Council funded Centre for Law, Gender and Sexuality was formed and funded for 5 years. ${ }^{26}$ Although that funding has now ended, projects continue and the Centre-spread across the universities of Keele, Kent and Westminster-has helped to create three substantial clusters of scholarship in the area of gender, sexuality and law. This 'pump-priming' of research has ensured not only that academics have been brought together, but also that new generations of younger academics are brought through. As these $\mathrm{PhD}$ students move into full-time academic posts across the sector, we can expect Gender, Sexuality and Law scholarship to become more established beyond these clusters and will likely look back at the Centre as crucial in the continued development of this area. These groupings join those small teams of scholars or lone scholars at other institutions working in this field-such as those at Birkbeck, Durham, the University of the West of England and Sunderland.

Despite this recent high profile imitative, this area of research has long historical roots with Moran ${ }^{27}$ noting Sir Edward Coke's exploration of 'buggery or sodomy' in the early Seventeenth Century as part of his larger four volume exposition of English law. Yet, it is perhaps precisely because of the law that this remains a relatively new area of scholarship in much the same way that women's study owed much to the liberation movement.

Gender, Sexuality and Law (or other permutations of the same three 'subjects') is perhaps less of a discipline and more of a territory. Thomas noted that territories 'are capable of being created, negotiated, conquered, exploited, developed and lost'. ${ }^{28}$ The fluid boundaries of this and other subjects means that papers that address technology and sexuality might be found in the Information Law Stream as much as in Gender, Sexuality and Law. Papers exploring the Civil Partnership Act could be reasonably located in the Family Law $^{29}$ stream as much as in GSL; so what is the function of a separate stream and why does it thrive amidst what Thomas called 'territorial uncertainty'?

Perhaps the answer lies in the move towards defining Gender, Sexuality and Law as a 'field'. ${ }^{30}$ Fletcher ${ }^{31}$ has argued that 'the making of the field happens through practice in a larger sense; through the embodied intellectual struggles that researchers have with logics and critiques, with their own energy and time, with each other'. In this sense, the GSL SLSA stream, in a significant way, contributes to producing a 'field'.

These struggles have, in recent years, been dominated by the Socio-Political developments of the last decade, particularly in the Anglo-American context which has placed issues of gender and sexuality high on the political and media agendas.

\footnotetext{
${ }^{26}$ http://www.kent.ac.uk/clgs/ (last accessed 23 March 2010).

27 Moran (2000).

28 Thomas (1997).

29 On the socio-legal aspects of family law see Jolly (1997).

${ }^{30}$ See, Conaghan (2009a); Hunter and Fletcher (2009); and Fletcher (2009).

31 Fletcher (2009).
} 
Gay Marriage, Civil partnerships, adoption rights, good and services rights, equality legislation, hate crime legislation and gender 'recognition' legislation has all contributed to stimulating a focus upon research into gender, sexuality and law. As Lee has noted, ${ }^{32}$ this relationship between social phenomena and legal response is one long established and engrained in the socio-legal tradition. The focus of the last decade upon equality in particular largely extinguished queer legal theory and the brief promise it had shown in the 1990s. The last few years have seen a resurgence in queer and the growth in texts and articles that engage with queer theory discourse in the last eighteen months suggests a growing theoretical response to the last decade's equality drive ${ }^{33}$ and the resulting construction of new hierarchies. ${ }^{34}$ Here, violence, not necessarily physical but perhaps moral or social, can take the form of the good/bad sex divide defined by Rubin, ${ }^{35}$ Robson's ${ }^{36}$ good/bad lesbian and Stychin's good gay/bad queer. ${ }^{37}$ These ideas can be seen as playing out in issues such as public sex ${ }^{38}$ and the barebacking phenomenon. ${ }^{39}$

Such was the focus upon equality, that recent legal developments have largely been placed within a rights discourse and as such draw upon a legal scholarship that emphasises the link between law and politics within the wider context of socio-legal studies. $^{40}$

It is this wider political debate that has done much to inform the field of gender, sexuality and law. Many of those involved in the field have personal stories that have informed their scholarship. For those in the UK who are recently retired, they grew up in a world in which homosexuality was illegal until 1967 whilst those still working within the Academy might have been of the 1970's, fighting for gay liberation or alternatively those who grew up in the 1980s and who were educated whilst Sect. 28 was in-force. This young group of academics voted for the first time during the late 1990s, at a time when the UK government was equalising the age of consent, repealing Sect. 28, introducing Civil partnerships and working towards equality.

Diduck $^{41}$ has noted that 'any field of study or inquiry, and [particularly gender, sexuality and law], is only comprised of the studies or inquiries of people, whether as individuals or groups, and that those studies cannot help but be informed by people's experiences, actions and interaction with others'. The radical change to law in England and Wales over the last decade is therefore likely to manifest itself in a shift in the experiences of those academics engaging in GSL scholarship in the next 10-20 years and their contribution will continue to re-shape and re-make this 'field'.

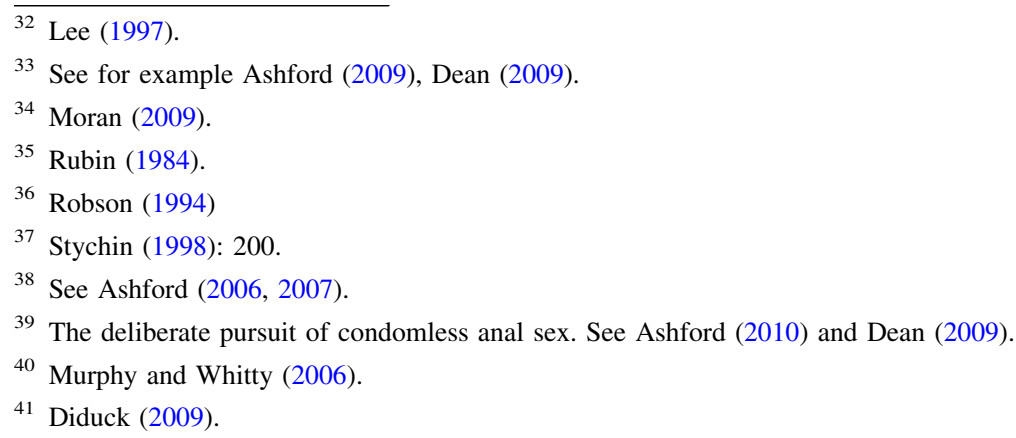


Gender, Sexuality and Law might therefore be said to naturally lend itself more to socio-legal study than black letter or doctrinal study and yet the historical location of gender in particular, and more recently sexuality, within the field of 'discrimination law' can lead to an approach more rooted in statute and case analysis than policy, society and theory. These differences of approach invariably lead to a range of views and different styles of teaching this area.

\section{Gender, Sexuality and Law Pedagogy}

Law Schools increasingly appear to be teaching these subjects. The most recent survey of UK Law schools found that $33 \%$ offered Gender and the Law as a subject/ module. ${ }^{42}$ It is not clear from this survey whether that encompasses sexuality but anecdotal evidence would suggest some courses do. A separate subject/module on sexuality was not listed at all in the Harris survey but it is known, again anecdotally, that such modules do exist today.

In the previous 1996 Harris survey, $19.9 \%$ of UK Law Schools offered Gender and the Law suggesting, together with anecdotal evidence, an upward trend in this subject. Interestingly, the 1996 survey also identified four Law Schools (6.1\%) offering Feminism and Law. ${ }^{43}$ This is another module that may in fact have been examining issues of sexuality and gender. The survey prior to this, produced by Wilson, ${ }^{44}$ did not identify specific modules in gender, feminism or sexuality.

In addition to the traditional academic forums, gender, sexuality and law has also taken advantage of the new technological developments of recent years. A number of blogs-particularly in the United States-have emerged that act as forums for sharing developments, offering rapid analysis and/or informal comment. ${ }^{45}$ These can further support not only the student experience, but also act as a catalyst for the 'intellectual struggles' that will help to further develop a 'field' of gender, sexuality and law.

Pedagogy perhaps also brings into sharp focus the question of methodologiesparticularly in the context of students' assignments and research supervision. Specific 'subjects', such as law and history have argued for their own methodological approaches to 'socio-legal'. ${ }^{46}$ For other subjects such as gender, sexuality and law, one has a plethora of methodological options from the social sciences and the humanities. Any attempt to assert a 'true' approach to the methodology for this subject or indeed any attempt to define the perimeters of this territory will surely fail. It is perhaps appropriate that is so given the queer tradition, which sees queer

\footnotetext{
42 Harris and Beinhart (2005).

43 Harris and Jones (1997).

44 Wilson (1993).

45 See for example: Nancy Polikoff's Beyond (Gay and Straight) Marriage blog: http://beyond straightandgaymarriage.blogspot.com/; the US group Feminist Law Professors: http://feminist lawprofessors.com/; Columbia Law School's Gender and Sexuality Law Blog: http://blogs.law. columbia.edu/genderandsexualitylawblog/; and Law and Sexuality at the University of Sunderland: http://lawandsexuality.blogspot.com/ (all last accessed 23 March 2010).

46 See for example: Rowbotham and Stevenson (2007).
} 
defined as "the open mesh of possibilities. Gaps, overlaps, dissonances and resonances, lapses and excesses of meaning when the constituent elements of anyone's gender, of anyone's sexuality aren't made (or can't be made) to signify monolithically'. ${ }^{7}$

Pedagogy also acts as a driver to bring forth questions of the personal. Robson noted in the 1990s that these courses can raise questions about personal revelation, self-censorship and boundaries of professional relations. She commented that: it seems like every pedagogical problem I have previously identified coalesces in the "finger fucking" class'. ${ }^{48}$ The class in question was examining the implications and interpretations of one case which also raised questions for her law students about lesbian sexuality. Robson went to conclude of the class that: 'it is the kind of class that makes me feel that, despite the problems, combining pedagogy, jurisprudence, and lesbian sex is worthwhile. It is the type of day that makes me think somehow of Sappho $^{49}$; maybe she should go to law school'. ${ }^{50}$

The divergent origins of gender, sexuality and law courses-whether they grew out of women's studies, feminist legal theory, human rights courses or are entirely new-together with the divergent backgrounds of course designers and tutors has resulted, perhaps unsurprisingly, in a range of different approaches, ${ }^{51}$ yet forums such as the SLSA offer an important space in which debates about these futures and approaches can take place.

\section{Socio-Legal Future(s) for Gender, Sexuality and Law}

In addition to providing a space for these academic debates, the GSL stream of the SLSA is also adapting to encompass a wider range of scholarship and ideas with films and poetry featuring alongside traditional academic papers. In doing so, Gender Sexuality and Law can be become even more rich, and ever more encompassing.

Perhaps one clue to the future(s) for gender, sexuality and law lies in the point made earlier, and discussed by Diduck ${ }^{52}$; that the field is informed by our 'experiences, actions and interactions'. Today's LGBTQ activists are increasingly internationally focussed-whether it be battles between sexuality and religion in Europe and Africa, a cultural awakening on gender and sexuality in China and the wider Asian region through globalisation or even 'rights' based debates around same-sex marriage and other equality measures in the United States. As activists, we petition, protest and debate, and so too as scholars we write and as teachers we share these stories.

\footnotetext{
47 Sedgwick (1994): 8.

48 Robson (1994): 223.

49 Ancient Greek female poet born on Lesbos.

50 Robson (1994): 224.

51 See more generally: Samuels (2009).

52 Diduck (2009).
} 
Theory has been a key component of gender and sexuality with postmodernism, feminism and queer being at the forefront in recent years. Whilst theory has been an important driver for change, it is also a product of that change. As we have seen greater doctrinal legal developments, so inevitably, do scholars turn to the theoretical to advance the field.

Debates within and from Feminism will no doubt continue to make an important contribution, ${ }^{53}$ but as we have recently begun to see, queer theory and queer legal theory is also once again making an important contribution, ${ }^{54}$ not least, because of the equality agenda of New Labour. ${ }^{55}$ Having equality as a norm will surely fuel speculation about the nature and value of equality-and questions about what next for the 'field'. It is possible that the goals of the last 50 years may be seen as a false dawn, an objective falsely pursued as a product of hetero-normative and patriarchal hegemony. It's going to be interesting.

\section{Introducing this Collection}

The articles in this short edited collection draw upon the work of new and emergent socio-legal scholars and well as experienced scholars. Some are in what $\mathrm{Lee}^{56}$ has described as 'the advocacy tradition' of socio-legal research, arguing for policy review and/or reform and together they offer a domestic and international approach to gender, sexuality and law.

Sue Farran, in her article, 'Pacific Perspectives: Fa'afafine and Fakaleiti in Samoa and Tonga: people between worlds' offers a fascinating insight into the labels used in Somoa and Tonga for gender and sexuality. In a fascinating piece, Farran argues that the legal environment, shaped by Colonialism, renders island inhabitants trapped between 'two worlds', what she terms 'gender-enlightened' and the 'gender repressed'. It is a reminder that our own western constructions are precisely thatnarrowly constructed in our Occidental legal cultures but due to colonialism, continue to have an international reach creating situations that demand socio-legal analysis and a questioning of international legal norms.

Julia Shaw turns to literature in her historical examination of gender roles. In, 'Against Myths and Traditions that Emasculate Women: Language, Literature, Law and Female Empowerment', Shaw passionately examines the historically rooted 'patriarchal moral ordering', concluding that although in 2010, legal doctrine ensures it remains largely a 'mans world', women can and must 'celebrate their distinct identity as a neglected core moral value'. Shaw reminds us of the importance of socio-legal analysis both historically and in contemporary law making.

Perhaps one of the most prominent sources for legal debate in Gender and Sexuality is the clash between liberal norms and religious doctrine-whether it is in

\footnotetext{
53 See more generally: Conaghan (2009b).

54 See more generally: Fineman et al. (2009).

55 See more generally: Ozimek (2009).

56 Lee (1997).
} 
the same-sex marriage debate or regarding expression rights. Maria Moscati, in her article, 'Trajectory of Reform: Catholicism, the State and Civil Society in the Development of LGBT Rights' examines two legal cultures, linked by a culture rooted in the Catholic faith. Moscati examines the different approaches to LGBT rights in Spain and Italy and puts forward an argument for legal reform in Italy through a consideration of moral norms, constructs of the family and an examination of socio-legal discourse.

In the final article, Sean Hennelly examines the role of the media in socio-legal discourse relating to law and sexuality. His paper, 'Public Space, Public Morality: The Media Construction of Sex in Public Places' considers the media reporting in UK newspapers of public sex environments. Hennelly offers a detailed examination of reports and concludes that newspapers have been 'irresponsible' in their reporting of public sex environments, particularly location details. Hennelly's piece acts to reawaken us to the importance of the media in the production and construction of law and how it continues to inform and define gender, sexuality and law.

\section{References}

Ashford, C. 2006. The only gay in the village: sexuality and the net. Information \& Communications Technology Law 13(3): 275.

Ashford, C. 2007. Sexuality and the criminal law: the cottaging phenomenon. Journal of Criminal Law 71(6): 506.

Ashford, C. 2009. Queer theory and researching online sex environments. Information \& Communications Technology Law 18(3): 297.

Ashford, C. 2010. Barebacking and the 'Cult of Violence': Queering the Criminal Law. Journal of Criminal Law, forthcoming.

Banakar, R., and M. Travers. 2005. Introduction. In Theory and Method in Socio-Legal Research, eds. Reza Banakar and Max Travers, ix-xvi. Oxford: Hart Publishing.

Bibbings, L. 2003. The future of higher education: 'sustainable research businesses' and 'exploitable knowledge'. Socio-Legal Newsletter 40: 1.

Bradshaw, A. 1997. Sense and sensibility: debates and developments in socio-legal research methods. In Socio-legal studies, ed. Philip A. Thomas, 99-122. Aldershot: Dartmouth Publishing Company Limited.

Burns, K., and T. Hutchinson. 2009. The impact of "empirical facts" on legal scholarship and legal research training. The Law Teacher 43(2): 153.

Carline, A., and H. Baker. 2008. Socio-legal studies in liverpool law schools, introduction. Liverpool Law Review 29(2): 117.

Collier, R. 2003. 'Useful knowledge' and the 'new economy': an uncertain future for (critical) socio-legal studies? Socio-Legal Newsletter 39: 3.

Collier, R. 2004. We're all socio-legal now? legal education, scholarship and the global knowledge economy, Reflections on the UK Experience. Sydney Law Review 26: 503.

Conaghan, J. 2009a. 'The making of a field or the building of a wall? feminist legal studies and law, gender and sexuality. Feminist Legal Studies 17: 303.

Conaghan, J. 2009b. Feminist legal studies: critical concepts in law. London: Routledge.

Cotterrell, R. 1995. Law's community: legal theory in sociological perspective. Oxford: Oxford University Press.

Cotterrell, R. 2002. Subverting orthodoxy, making law central: a view of sociolegal studies. Journal of Law and Society 29(4): 632.

Cowan, D., S. Wheeler, and P. Hillyard. 2003. What is the state of socio-legal training in UK law schools?: SLSA questionnaire results. Socio-Legal Newsletter 39: 1. 
Cownie, F. 2004a. Legal academics: culture and identities. Oxford: Hart Publishing.

Cownie, F. 2004b. Researching (Socio) legal academics. Socio-Legal Newsletter 42: 1.

Dean, T. 2009. Unlimited intimacy: reflections on the subculture of barebacking. Chicago: University of Chicago Press.

Diduck, A. 2009. Doing home. Feminist Legal Studies 17: 293.

ESRC. 1994. Review of socio-legal studies: final report. Swindon: ESRC.

Fineman, M.A., J.E. Jackson, and A.P. Romero. 2009. Feminist and queer legal theory: intiamte encounters, uncomfortable conversations. Farnham: Ashgate.

Fitzpatrick, P. 1995. Being social in socio-legal studies. Journal of Law and Society 22(1): 105.

Fletcher, R. 2009. Embodied practices. Feminist Legal Studies 17: 315.

Galligan, D. 1995. Socio-legal studies in context: the oxford centre past and present, introduction. Journal of Law and Society 22(1): 1.

Genn, H., Partington, M., and Wheeler, S. 2006. Law in the real world: improving our understanding of how law works, final report and recommendations. London: Nuffield Foundation. Available at: http://www.ucl.ac.uk/laws/socio-legal/empirical/.

Golder, B., and P. Fitzpatrick. 2009. Foucault's law. Abingdon: Routledge-Cavendish.

Harris, P., and S. Beinhart. 2005. A survey of law schools in the United Kingdom 2004. The Law Teacher 39(3): 299.

Harris, P., and M. Jones. 1997. A survey of law schools in the United Kingdom 1996. The Law Teacher 31(1): 38 .

Hillyard, P. 2002. Invoking indignation: reflections on future directions of socio-legal studies. Journal of Law and Society 29(4): 645.

Hillyard, P. 2007. Law's empire: socio-legal empirical research in the twenty-first century. Journal of Law and Society 34(2): 266.

Hunt, A. 1994. Governing the socio-legal project: or what do research councils Do? Journal of Law and Society 21: 522 .

Hunter, R., and R. Fletcher. 2009. Law, gender and sexuality: the making of a field. Feminist Legal Studies 17: 289.

Jolly, S. 1997. Family law. In Socio-legal studies, ed. Philip A. Thomas, 342-358. Aldershot: Dartmouth Publishing Company Limited.

Lacey, N. 1998. Unspeakable subjects. Oxford: Hart Publishing.

Lee, R. 1997. Socio-legal research-what's the use? In Socio-legal studies, ed. Philip A. Thomas, 76-98. Aldershot: Dartmouth Publishing Company Limited.

McKee, A. 2009. Social scientists don't say 'Titwank'. Sexualities 12: 629.

Moran, L.J. 2000. Homo legalis: lesbian and gay in legal studies. In Lesbian and gay studies: an introductory interdisciplinary approach, ed. Theo Sandfort, Judith Schuyf, Jan W. Duyvendak, and Jeffrey Weeks, 98-112. London: Sage Publications.

Moran, L.J. 2009. What kind of field if 'law, gender and sexuality'? achievements, concerns and possible futures. Feminist Legal Studies 17: 309.

Moran, L., B. Skeggs, P. Tyer, and K. Corteen. 2004. Sexuality and the politics of violence and safety. London: Routledge.

Murphy, T., and N. Whitty. 2006. A question of definition: feminist legal schoalrship, socio-legal studies and debate about law \& politics. Northern Ireland Legal Quarterly 57(3): 539.

Nelkin, D. 1981. The 'gap problem' in the sociology of law: a theoretical review. Windsor Yearbook of Access to Justice 35.

Ozimek, J. 2009. 'Sex in the noughties: how was it for you? The Register, 31 December, http://www.theregister.co.uk/2009/12/31/noughties_review/page3.html (last accessed 22 March 2010).

Partington, M. 1997. Socio-legal research in britain: shaping the funding environment. In Socio-legal studies, ed. Philip A. Thomas, 23-44. Aldershot: Dartmouth Publishing Company Limited.

Robson, R. 1994. Resisting the family: repositioning lesbian in legal theory. Signs: Journal of Women in Culture and Society 19(4): 975.

Rowbotham, J., and K. Stevenson. 2007. Editorial: answering baker: utilising best evidence. The challenge for socio-legal studies. Liverpool Law Review 28(3): 319.

Rubin, G. 1984. Thinking sex: notes for a radical theory of the politics of sexuality. In Please and danger: exploring female sexuality, ed. Carole S. Vance, 267-319. London: Routledge.

Samuels, H. 2009. An uneasy alliance? The relationship between feminist legal studies and gender, sexuality and law. Feminist Legal Studies 17: 297. 
Sedgwick, E. 1994. Tendencies. Durham: Duke University Press.

SLSA. 2009. Statement of Principles of Ethical Research Practice. Available at: http://www.kent.ac.uk/ nslsa/images/slsadownloads/ethicalstatement/slsa\%20ethics\%20statement\%20_final_\%5B1\%5D. pdf (last accessed 24 March 2010).

Stychin, C.F. 1998. A Nation by rights. Philadelphia: Temple University Press.

Thomas, P.A. 1997. Socio-legal studies: the case of disappearing fleas and bustards. In Socio-legal studies, ed. Philip A. Thomas, 1-22. Aldershot: Dartmouth Publishing Company.

Travers, M. 2001. Sociology of Law in Britain. The American Sociologist 32(2): 26.

Twining, W. 1995. Remembering 1972: The oxford centre in the context of developments in higher education and the discipline of law. Journal of Law and Society 22(1): 35.

Voiculescu, A. 2008. Mind the Gap: Socio-legal scholarship for a runaway world. Journal of Commonwealth Law and Legal Education 6(1): 1.

Wheeler, S. 2009. Goodbye to all that. Socio-Legal Newsletter 57: 1.

Wilson, J. 1993. A third survey of university legal education in the United Kingdom. Legal Studies 13(2): 143.

Witherspoon, S. 2002. Research capacity: a crisis in waiting? Socio-Legal Newsletter 37: 1. 